\title{
ESTONIAN PORPHYRACEOUS POTASSIUM GRANITES: PETROCHEMICAL SUBDIVISION AND PETROGENETICAL INTERPRETATION
}

\author{
Alvar SOESOO
}

Eesti Teaduste Akadeemia Geoloogia Instituut (Institute of Geology, Estonian Academy of Sciences), Estonia pst. 7, EE-0100 Tallinn, Eesti (Estonia)

Presented by V. Puura

Received November 30, 1992; accepted March 23, 1993

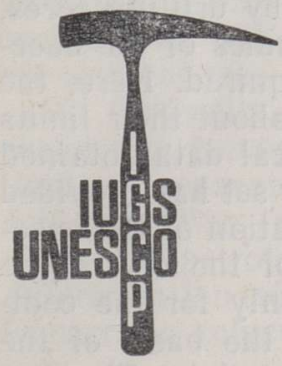

Project 275

Baltic Shield and

Project 315

Rapakivi Granites

\begin{abstract}
The petrochemistry of the Estonian porphyraceous granites was studied on the basis of 98 chemical analyses from 60 drill cores penetrating 5 granite plutons. Using cluster analysis with the Niggli main values as input data, five main and five intermediate petrochemical varieties of the granites were distinguished. The distribution of the granite varieties of the Neeme and Märjamaa plutons is presented. Two basic varieties of granites $\left(\mathrm{SiO}_{2} \leqslant 67 \%\right)$ chemically close to quartz-monzonite and granodiorite, occurring mostly in the Märjamaa and in a limited amount in the Neeme pluton, are considered to be rocks of the first intrusive phase. Leucocratic granites, interpreted as the second intrusive stage, do not directly correspond to the "average" granite varieties. The petrochemical nature and distribution of the intermediate granite subtypes allow us to regard those as contact-type varieties. Chemically homogeneous and the most leucocratic granite sub. type forms the central part of the Neeme pluton and is inter-
\end{abstract} preted as the "end-member" of the evolution of the granitic plutons. Chemical and petrological inhomogeneities on the present erosion level inside and between plutons have been induced by many processes such as assimilation of the first intrusive phase and secondary alteration. Also, the local inhomogeneity of plutons has been influenced by the size of magmatic body and its geometry, especially in marginal zones.

Key words: petrochemistry, classification, potassium granites, Precambrian, Estonia.

\section{INTRODUCTION}

This study is a contribution to IGCP Projects No. 275 and 315 being a continuation of the studies of Estonian porphyraceous potassium (Epp.) granites. A previous study deals with the petrography and general petrochemistry of these granites (Soesoo \& Niin, 1992).

Mineralogically, Epp. granites are biotite-granites with porphyritic texture, containing quartz, microcline, plagioclase, and biotite as main minerals, and also hornblende and muscovite. The most common accessory minerals are apatite, fluorite, sphene, zircon, and opaque minerals. 
It has been pointed out in several studies that the Epp. granites and the typical rapakivi granites have similarities in their mineralogical and chemical composition and a close age span (Пуура et al., 1974; Кууспалу, 1975; Великославинский et al., 1978; Кирс et al., 1990; Kirs et al., 1991; Soesoo \& Niin, 1992). By their small size and many structural and textural features, the Epp. granites are comparable with Finnish plutons of rapakivi-like granites of approximately the same size. However, no detailed comparative petrochemical studies of Estonian and Finnish granites have been conducted.

The purpose of this study is petrochemical classification of Epp. granites using cluster analysis of petrochemical data and subsequent petrological interpretation of clusters. An attempt was made to divide the Estonian granites into subgroups interpretable from petrological point of view as products of several geological/magmatic processes.

In the present study, 98 wet chemical analyses from 60 drill cores of 5 Estonian granitic plutons and petrographical descriptions published by Soesoo \& Niin (1992) have been used.

\section{THEORETICAL APPROACHES AND METHODS}

In Estonia, where the crystalline basement is covered by about $100-$ $800 \mathrm{~m}$ thick sedimentary rocks and can be reached only by drilling cores, an approach slightly different from that used for the studies of the basement exposure areas, e. g. Fennoscandian Shield, is required. Here, the rock bodies cannot be visually traced, and assumptions about their limits can be made on the basis of petrological and petrochemical data obtained from core studies. At the same time, a very dense drilling set has provided a number of cores which can be used for the characterization of the basement rocks. Traditionally, the studies of the geology of the crystalline basement of Estonia have used petrochemical data mainly for the comparison of the different rock complexes established on the basis of the petrographical descriptions of the cores and geophysical data. The empirical data set available from the core studies includes a series of chemical analyses of the core samples. The samples have been taken from the parts of the cores assumed to be homogeneous by visual examination. Thus, the set of chemical analyses corresponding to petrographically determined rock types must be taken as a set of statistical entities and the results of the analysis of each single sample must be taken as a random unit.

Applying the statistical analysis of petrochemical data, an attempt is made here to seek for the parameters and criteria allowing to distinguish petrochemically different varieties of the granites studied and to characterize their variation.

In selection and modification of the raw data set for the statistical processing, the following considerations have been taken into account. (1) Chemical analyses, which by definition must sum to a constant value - $100 \%$, are independent of the size of the system and the data comprise what statisticians refer to as a closed array. Correlation and variance arising from closure may be misconstrued to be produced by geological material transfer processes (Russell and Stanley, 1990). From a petrological point of view, the major handicap of working with closed data arrays is, rather than the potential distortion of statistics, that the true relationships between extensive variables are obscured by closure. Using these chemical data (10-12 oxides), the majority of classification methods may be made excessively sensitive. (2) The designing of informative elements and their use as characteristics in classification cannot 
yield good results because in different tectono-magmatic situations and also depending on the initial type of magma the evolution of the magmatic system has been controlled by different factors. (3) Also, the number of variables must be restricted and they must be petrologically comparable characteristics, e. g. atomic amounts and their ratios.

For classification, cluster analysis with Euclidian distances used for calculating the distance matrix has been applied. Trying different modifications of the raw data sets, the best results were obtained using five Niggli main values as input data. The interpretation of the hierarchical structure of clusters allows to distinguish different petrological varieties and to estimate their relations, which often have a dynamic character.

\section{PETROCHEMICAL CLASSIFICATION AND CHARACTERISTICS OF THE ESTONIAN PORPHYRACEOUS GRANITES}

The results of the cluster analysis of 98 samples using the Niggli main values as input data and Euclidian distance metrics for computing the distance matrix are displayed in Fig. 1 as a simplified hierarchical tree. Interpretation of these results groups the samples of the Epp. granites of five plutons into five main ( $A, B, D, E$, and $F$ ) and five intermediate clusters referred to as subtypes of granites. The clusters have a substructure in some cases. Subsequently, mean Niggli values and ratios for each cluster were calculated (Table 1). Analysis of the structure of the hierarchical tree and the Niggli main values suggest the following:

1. Generally, the rocks of the Estonian granitic plutons are not chemically homogeneous. These inhomogeneities can be expressed in the limits of separate plutons and are in some cases observable in a single drill core (Fig. 1; Tables 1 and 2).

2. The petrological subtypes interpreted as the two end-members of the differentiation scale - the most melanocratic (cluster F) and the most leucocratic (cluster D) granites - have the most homogeneous composition.

Below the descriptions of clusters on the basis of Niggli main values are presented. Fig. 2 displays the dynamics of these values of ten clusters. Two solid lines indicate the dynamics of the two end-members. The dashed line denotes averaged values of the end-members. From the input data of 98 samples, 91 were used for interpretation and description of subtypes.

Table I

Average Niggli main values and ratios of clusters of the Estonian porphyraceous granites (after cluster analysis)

\begin{tabular}{l|c|r|r|r|r|r|r|r|r}
\hline Cluster & al & $f m$ & $c$ & alk & si & clfm & al/fm & clalk & fm/c+alk \\
\hline A & 38.4 & 17.2 & 12.0 & 32.4 & 359 & 0.70 & 2.24 & 0.37 & 0.39 \\
B & 41.2 & 15.3 & 9.5 & 34.0 & 386 & 0.62 & 2.68 & 0.28 & 0.35 \\
D & 42.7 & 13.6 & 9.9 & 33.9 & 444 & 0.73 & 3.14 & 0.29 & 0.31 \\
E & 35.7 & 24.3 & 12.9 & 27.1 & 290 & 0.53 & 1.47 & 0.48 & 0.61 \\
F & 32.2 & 30.8 & 14.5 & 22.5 & 246 & 0.47 & 1.05 & 0.65 & 0.83 \\
$\mathrm{C}_{1}$ & 39.5 & 16.3 & 8.7 & 35.6 & 402 & 0.53 & 2.43 & 0.24 & 0.37 \\
$\mathrm{C}_{2}$ & 42.2 & 16.6 & 10.3 & 30.9 & 396 & 0.62 & 2.54 & 0.33 & 0.40 \\
$\mathrm{C}_{3}$ & 43.1 & 16.0 & 12.4 & 28.7 & 409 & 0.76 & 2.69 & 0.43 & 0.39 \\
$\mathrm{C}_{4}$ & 38.7 & 17.8 & 10.4 & 33.1 & 339 & 0.59 & 2.18 & 0.32 & 0.41 \\
$\mathrm{C}_{5}$ & 40.7 & 17.0 & 8.5 & 33.7 & 384 & 0.50 & 2.39 & 0.25 & 0.40
\end{tabular}



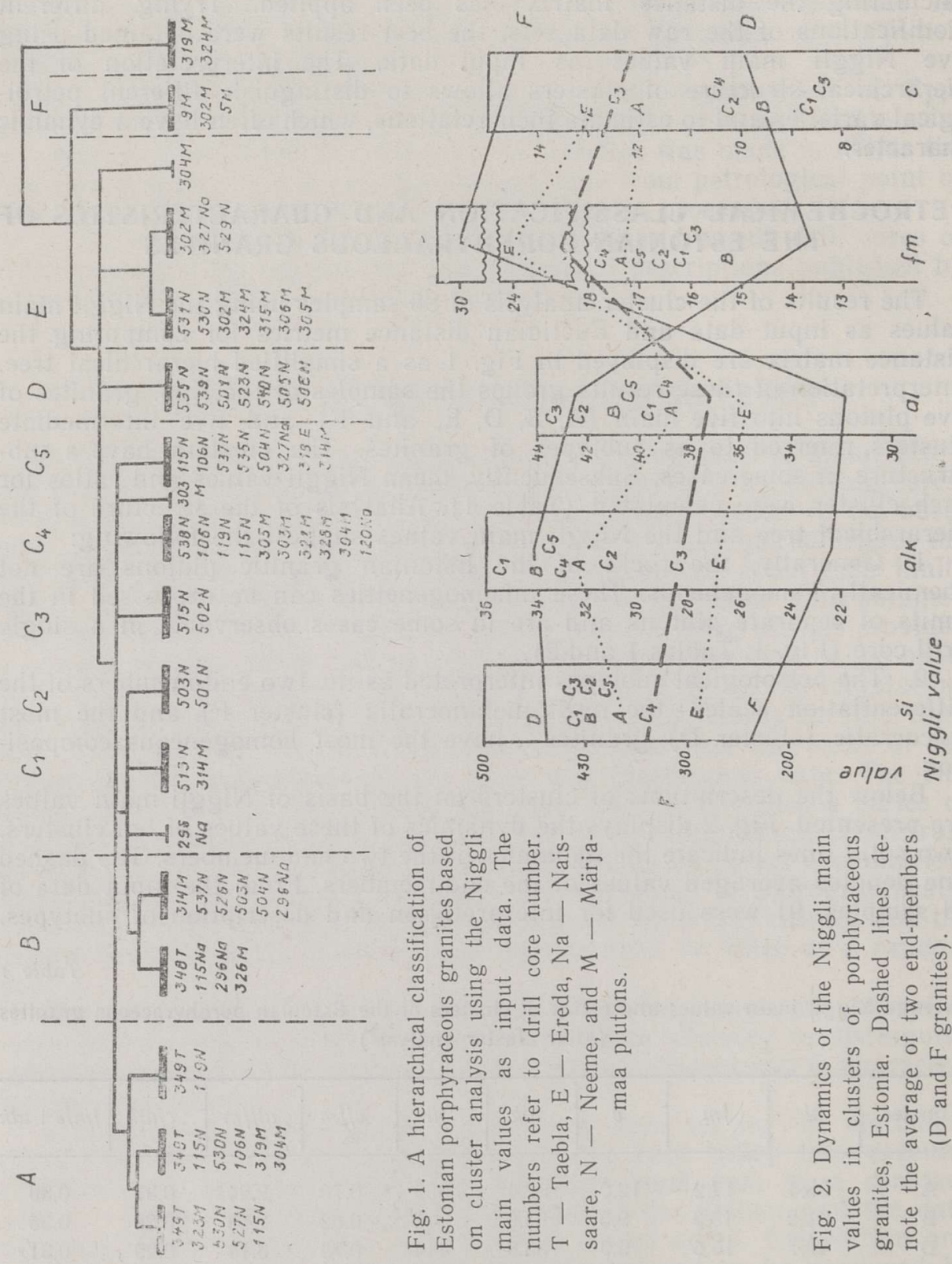
Average chemical composition, standard devation (Std.), variance as $\mathrm{Std} / \mathrm{n}$, and real chemical analysis (samples) of main and intermediate clusters (M-Märjamaa; N-Neeme plutons) of the Estonian porphyraceous granites (after cluster analysis)

\begin{tabular}{|c|c|c|c|c|c|c|c|c|c|c|c|c|c|}
\hline Indexes & in & 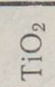 & 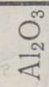 & $0_{\mathbb{N}}^{\infty}$ & $\begin{array}{l}0 \\
0 \\
\text { I }\end{array}$ & ${ }^{\circ}$ & ${ }_{\substack{0 \\
\sum^{\infty}}}$ & 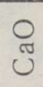 & $\begin{array}{l}\text { O } \\
\text { Z }\end{array}$ & Oo & $0^{\infty}$ & is & $\begin{array}{l}O_{1}^{*} \\
\text { I }\end{array}$ \\
\hline
\end{tabular}

Cluster F

Sample M9

Std.

Var.

Cluster E

Sample M302

Std.

Var.

Cluster A

Sample N115

Std.

Var.

Cluster B

Sample N503

Std.

Var.

Cluster D

Sample N540

Std.

Var.

Cluster $\mathrm{C}_{1}$

Sample N513

Std.

Var.

Cluster $\mathrm{C}_{2}$

Sample N503

Std.

Var.

Cluster $\mathrm{C}_{3}$

Std.

Var.

Cluster $\mathrm{C}_{4}$

Sample M322

Std.

Var.

Cluster $\mathrm{C}_{5}$

Std.

Var, $\begin{array}{lllllllllllll}64.05 & 0.96 & 14.19 & 3.34 & 3.49 & 0.19 & 1.61 & 3.53 & 2.68 & 5.11 & 0.46 & 0.15 & 0.26\end{array}$ $\begin{array}{lllllllllllll}64.16 & 0.89 & 14.00 & 3.81 & 3.10 & 0.28 & 1.78 & 3.40 & 2.50 & 5.15 & 0.48 & 0.18 & 0.33\end{array}$ $\begin{array}{lllllllllllll}0.39 & 0.08 & 0.51 & 0.34 & 0.27 & 0.10 & 0.27 & 0.18 & 0.18 & 0.42 & 0.02 & 0.04 & 0.10\end{array}$ $\begin{array}{lllllllllllll}0.13 & 0.03 & 0.17 & 0.11 & 0.09 & 0.03 & 0.09 & 0.06 & 0.06 & 0.14 & 0.01 & 0.01 & 0.03\end{array}$

$\begin{array}{lllllllllllll}66.85 & 0.70 & 13.94 & 1.75 & 3.11 & 0.09 & 1.17 & 2.82 & 2.80 & 5.40 & 0.27 & 0.11 & 0.15\end{array}$ $\begin{array}{lllllllllllll}66.06 & 0.93 & 13.51 & 2.21 & 3.18 & 0.02 & 1.60 & 2.93 & 2.88 & 5.05 & 0.39 & 0.08 & 0.13\end{array}$ $\begin{array}{lllllllllllll}1.09 & 0.24 & 0.91 & 0.60 & 0.99 & 0.03 & 0.35 & 0.55 & 0.41 & 1.36 & 0.11 & 0.04 & 0.05\end{array}$ $\begin{array}{lllllllllllll}0.05 & 0.01 & 0.04 & 0.03 & 0.05 & 0.00 & 0.02 & 0.03 & 0.02 & 0.06 & 0.01 & 0.00 & 0.00\end{array}$

$\begin{array}{lllllllllllll}71.31 & 0.35 & 12.99 & 1.20 & 1.88 & 0.05 & 0.65 & 2.25 & 2.76 & 5.77 & 0.09 & 0.12 & 0.18\end{array}$ $\begin{array}{lllllllllllll}71.30 & 0.38 & 12.64 & 1.39 & 1.89 & 0.03 & 0.60 & 2.53 & 2.80 & 5.90 & 0.13 & 0.05 & 0.16\end{array}$ $\begin{array}{lllllllllllll}0.93 & 0.09 & 0.39 & 0.46 & 0.43 & 0.02 & 0.18 & 0.32 & 0.49 & 0.53 & 0.04 & 0.05 & 0.06\end{array}$ $\begin{array}{lllllllllllll}0.06 & 0.01 & 0.02 & 0.03 & 0.03 & 0.00 & 0.01 & 0.02 & 0.03 & 0.03 & 0.00 & 0.00 & 0.00\end{array}$

$\begin{array}{lllllllllllll}72.29 & 0.24 & 13.11 & 1.19 & 1.54 & 0.05 & 0.51 & 1.64 & 3.14 & 5.24 & 0.07 & 0.10 & 0.16\end{array}$ $\begin{array}{lllllllllllll}72.46 & 0.22 & 13.77 & 1.08 & 1.36 & 0.05 & 0.75 & 1.99 & 2.30 & 5.00 & 0.08 & 0.10 & 0.09\end{array}$ $\begin{array}{lllllllllllll}0.34 & 0.07 & 0.57 & 0.66 & 0.52 & 0.01 & 0.19 & 0.32 & 1.51 & 1.46 & 0.04 & 0.04 & 0.05\end{array}$ $\begin{array}{lllllllllllll}0.03 & 0.01 & 0.05 & 0.06 & 0.05 & 0.00 & 0.02 & 0.03 & 0.14 & 0.13 & 0.00 & 0.00 & 0.00\end{array}$ $\begin{array}{lllllllllllll}75.41 & 0.17 & 12.01 & 0.90 & 1.22 & 0.04 & 0.40 & 1.59 & 2.53 & 5.02 & 0.05 & 0.12 & 0.10\end{array}$

$\begin{array}{lllllllllllll}74.70 & 0.15 & 12.22 & 0.66 & 1.44 & 0.03 & 0.39 & 1.38 & 2.50 & 5.36 & 0.07 & 0.13 & 0.09\end{array}$ $\begin{array}{lllllllllllll}0.47 & 0.06 & 0.37 & 0.31 & 0.36 & 0.01 & 0.05 & 0.27 & 0.42 & 0.39 & 0.02 & 0.02 & 0.02\end{array}$ $\begin{array}{lllllllllllll}0.06 & 0.01 & 0.05 & 0.04 & 0.05 & 0.00 & 0.01 & 0.03 & 0.05 & 0.05 & 0.00 & 0.00 & 0.00\end{array}$

$\begin{array}{lllllllllllll}72.71 & 0.27 & 12.30 & 0.87 & 1.75 & 0.05 & 0.50 & 1.80 & 2.43 & 6.13 & 0.11 & 0.10 & 0.17\end{array}$ $\begin{array}{lllllllllllll}72.96 & 0.23 & 12.74 & 0.65 & 1.72 & 0.06 & 0.62 & 1.49 & 2.35 & 5.90 & 0.10 & 0.10 & 0.15\end{array}$ $\begin{array}{lllllllllllll}0.57 & 0.06 & 0.54 & 0.13 & 0.29 & 0.01 & 0.11 & 0.59 & 0.29 & 0.32 & 0.09 & 0.08 & 0.05\end{array}$ $\begin{array}{lllllllllllll}0.14 & 0.02 & 0.14 & 0.03 & 0.07 & 0.00 & 0.03 & 0.15 & 0.07 & 0.08 & 0.02 & 0.02 & 0.01\end{array}$

$\begin{array}{lllllllllllll}72.41 & 0.27 & 13.04 & 1.36 & 1.35 & 0.05 & 0.55 & 1.76 & 1.88 & 6.00 & 0.07 & 0.10 & 0.15\end{array}$ $\begin{array}{lllllllllllll}72.88 & 0.28 & 13.23 & 1.16 & 1.51 & 0.06 & 0.62 & 2.11 & 2.45 & 4.36 & 0.08 & 0.10 & 0.15\end{array}$ $\begin{array}{lllllllllllll}0.34 & 0.04 & 0.17 & 0.15 & 0.32 & 0.01 & 0.05 & 0.26 & 0.53 & 1.39 & 0.02 & 0.02 & 0.04\end{array}$ $\begin{array}{lllllllllllll}0.11 & 0.01 & 0.06 & 0.05 & 0.11 & 0.00 & 0.02 & 0.09 & 0.18 & 0.46 & 0.01 & 0.01 & 0.01\end{array}$

$\begin{array}{lllllllllllll}73.16 & 0.27 & 13.06 & 0.89 & 1.72 & 0.06 & 0.48 & 2.06 & 2.53 & 4.19 & 0.07 & 0.10 & 0.11\end{array}$ $\begin{array}{lllllllllllll}0.18 & 0.03 & 0.44 & 0.28 & 0.44 & 0.01 & 0.06 & 0.07 & 0.07 & 0.08 & 0.03 & 0.00 & 0.02\end{array}$ $\begin{array}{lllllllllllll}0.09 & 0.02 & 0.22 & 0.14 & 0.22 & 0.01 & 0.03 & 0.04 & 0.04 & 0.04 & 0.02 & 0.00 & 0.01\end{array}$

$\begin{array}{lllllllllllll}70.00 & 0.35 & 13.67 & 1.20 & 1.94 & 0.06 & 0.67 & 2.06 & 2.95 & 6.10 & 0.07 & 0.08 & 0.16\end{array}$ $\begin{array}{lllllllllllll}70.92 & 0.37 & 14.04 & 1.12 & 1.36 & 0.07 & 0.80 & 2.01 & 3.26 & 6.26 & 0.04 & 0.07 & 0.07\end{array}$ $\begin{array}{lllllllllllll}0.71 & 0.15 & 0.96 & 0.56 & 0.60 & 0.03 & 0.21 & 0.43 & 0.73 & 0.96 & 0.04 & 0.06 & 0.08\end{array}$ $\begin{array}{lllllllllllll}0.07 & 0.02 & 0.10 & 0.06 & 0.06 & 0.00 & 0.02 & 0.04 & 0.07 & 0.10 & 0.00 & 0.01 & 0.01\end{array}$

$\begin{array}{lllllllllllll}71.08 & 0.36 & 13.18 & 1.16 & 2.05 & 0.05 & 0.68 & 1.97 & 2.40 & 5.69 & 0.09 & 0.17 & 0.22\end{array}$ $\begin{array}{lllllllllllll}2.18 & 0.17 & 0.62 & 0.47 & 0.72 & 0.02 & 0.34 & 0.73 & 0.55 & 0.83 & 0.06 & 0.19 & 0.10\end{array}$ $\begin{array}{lllllllllllll}0.24 & 0.02 & 0.07 & 0.05 & 0.08 & 0.00 & 0.04 & 0.08 & 0.06 & 0.09 & 0.01 & 0.02 & 0.01\end{array}$ 


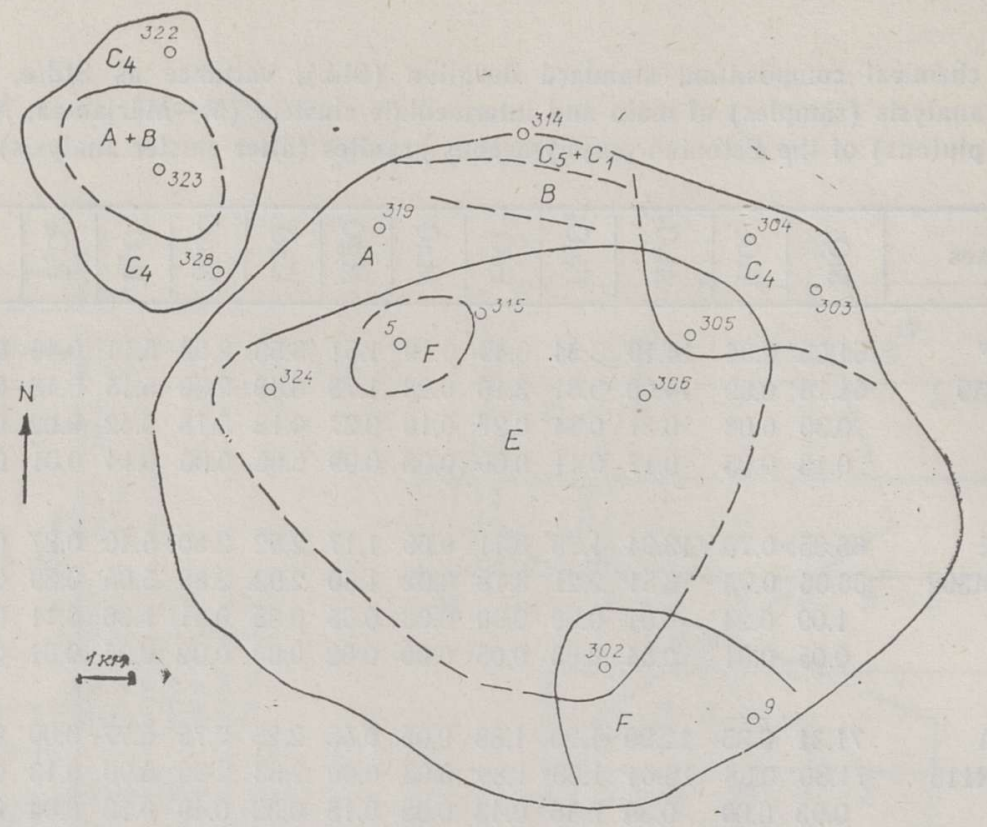

Fig. 3. The distribution of subtypes of granites of the Märjamaa pluton. A, B, F .. petrochemical groups of granites according to cluster analysis.

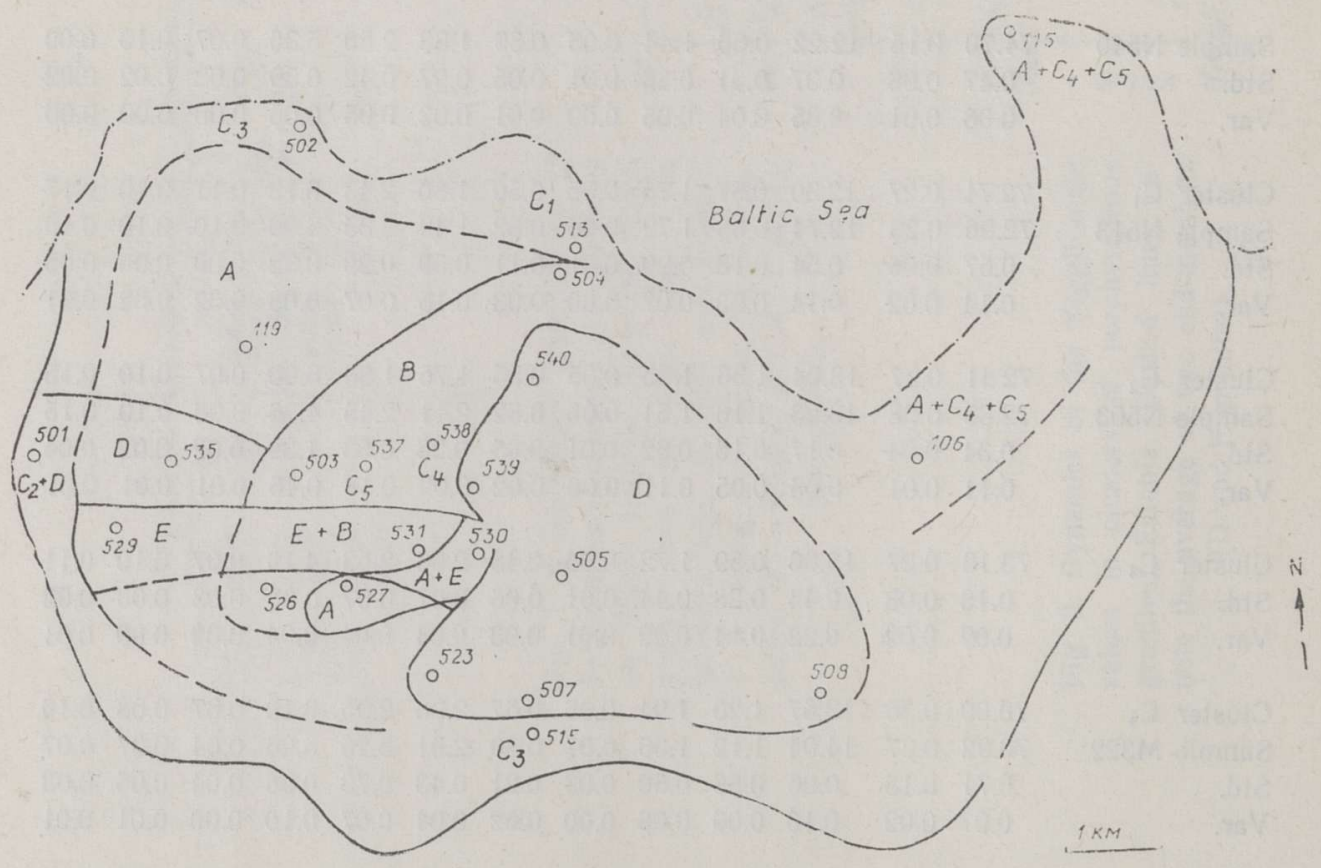

Fig. 4. The distribution of subtypes of granites of the Neeme pluton. A, B, D ... petrochemical groups of granitẹs according to clustẹr analysis, 
CLUSTER $F$ includes the most melanocratic part of Epp. granites, which have been described in three drill cores of Märjamaa pluton (three samples; Fig. 1). Chemically they are similar to the quartz-monzonites, revealing also prints of more basic affinities.

CLUSTER E consists of chemically more evolved granites (20 samples; Fig. 2) and includes the majority of samples of the Neeme pluton petrographically described as the first phase, as well as many samples of the Märjamaa pluton, and also one sample of the Naissaare pluton. As compared to the $\mathrm{F}$ granites, the $\mathrm{E}$ granites have a higher silica content, lower $\mathrm{Fe}_{2} \mathrm{O}_{3} / \mathrm{FeO}$ ratio (about $1: 2$ vs. $1: 1$ ), and an almost equal content of $\mathrm{K}_{2} \mathrm{O}$ (Table 2). Chemically, the $\mathrm{E}$ granites are close to granodiorites.

CLUSTER A includes altogether 18 samples of Taebla (except drill core No. 348), Märjamaa (drill cores $323,319,304$; see Fig. 3), and Neeme $(530,527,115,106,119$; Fig. 4) granites. The dynamics of petrogenical components expressed by Niggli main values is close to the averaged values in Fig. 2, but somewhat higher alk inclines these characteristics to the direction of a more acid field. The granites of cluster A are enriched in alkali (as compared to the si value); this is petrographically expressed by more frequent occurrences of potash feldspar characteristic of these granites. Relatively high $f m$ value -17.2 - inherited from more basic primary magmas shows a possible relation with subtype E. Slightly higher content of $\mathrm{Fe}$ and $\mathrm{Ca}$, and lower content of $\mathrm{Al}$ and $\mathrm{Mg}$ differentiate A granites from average "normal" granites.

CLUSTER B, comprising a total of 11 samples from Taebla (1), Neeme (4), Märjamaa (3), and Naissaare (3) plutons, represents the granite subtype characterized by high $a l$ and alk values: 41.2 and 34.0 , respectively (Table 1$)$. It can be noted that the high alkalinity is caused by high $\mathrm{Na}_{2} \mathrm{O}$ content - on the average $3.14 \%$ (Table 2). Also, low fm and $c$ values are typical. It is difficult to correlate these granites with any concrete type of granitoids. B granites occupy the lower part in an evolutionary trend being not directly related with other main clusters and displaying several characteristics similar to the intermediate clusters (subtypes). The structure of the hierarchical tree shows that B granites have the closest relation to $C_{1}$ and $C_{2}$ granites from which they can be distinguished by the differences in $\mathrm{Na}$ and $\mathrm{K}$ contents.

CLUSTER D, the chemically most homogeneous granite subtype, is represented by eight samples of the Neeme pluton. The highest values of $a l, s i, a l / f m$ and the lowest values of $f m$ allow to interpret these granites as the end-member of differentiation/evolution. The silica-rich D granites are depleted of $\mathrm{Ca}, \mathrm{Mg}$, and $\mathrm{Fe}$, but the content of $\mathrm{Na}_{2} \mathrm{O}$ and $\mathrm{K}_{2} \mathrm{O}$ is close to that of the $\mathrm{E}$ and $\mathrm{F}$ melanocratic granites.

Interpretation of clusters $C_{1}, C_{2}, C_{3}, C_{4}$, and $C_{5}$ (Fig. 1) as separate subtypes of granites is disputable, because they are represented by few samples (2-4) and on the basis of five variables these granites may be incorporated in some other main clusters. On the other hand, relatively high or low values of some variable discriminate those from the others. Location of samples (drill cores) corresponding to the mentioned clusters facilitates the interpretation of the nature of intermediate clusters (Figs. 3 and 4). Cluster $C_{1}$ is represented by one sample of the Neeme and two samples of the Märjamaa pluton located in the contact zone and characterized by the lowest al/fm, c, fm ratios, and high alk. Granites of cluster $\mathrm{C}_{2}$ are close to cluster $\mathrm{B}$, though they have a systematically lower alkali content (caused by low Na) (Table 2). Two samples from the Neeme pluton differing from others in high si and $c$ and anomalously low alk values (as compared to si), are presented as cluster $\mathrm{C}_{3}$. They have the highest $c / f m$ value -0.76 (Table 1) comparable with the most melanocratic varieties indicating that the processes of acid-basic differentiation 
Average Niggli main values corresponding to the clusters of Märjamaa granites distinguished using cluster analysis

\begin{tabular}{|c|c|c|c|c|c|c|c|c|c|c|}
\hline 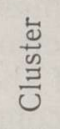 & $\begin{array}{l}\text { Drill core } \\
\& \text { number } \\
\text { of samples * }\end{array}$ & $\bar{z}$ & $E$ & 0 & ฮี & $\vec{\omega}$ & $\frac{E}{0}$ & $\frac{\Xi}{\tilde{\sigma}}$ & $\frac{\tilde{a}}{0}$ & $\begin{array}{l}\vec{J} \\
+ \\
0 \\
\vdots \\
\vdots\end{array}$ \\
\hline \multirow[t]{2}{*}{1.1} & $3024 / 7$ & & & & & & & & & \\
\hline & $3031 / 3$ & 34.16 & 26.86 & 13.16 & 25.88 & 274 & 0.49 & 1.27 & 0.51 & 0.69 \\
\hline \multirow[t]{3}{*}{1.2} & $3242 / 2$ & & & & & & & & & \\
\hline & $3062 / 2$ & & & & & & & & & \\
\hline & $\begin{array}{r}3021 / 7 \\
91 / 1\end{array}$ & 31.76 & 26.98 & 14.66 & 24.58 & 290 & 0.54 & 1.18 & 0.60 & 0.69 \\
\hline \multirow{4}{*}{1.3} & $51 / 1$ & & & & & & & & & \\
\hline & $3022 / 7$ & & & & & & & & & \\
\hline & $3031 / 3$ & & & & & & & & & \\
\hline & $3221 / 2$ & 34.08 & 26.55 & 14.13 & 25.22 & 280 & 0.53 & 1.28 & 0.56 & 0.67 \\
\hline \multirow[t]{4}{*}{2.} & $3282 / 3$ & & & & & & & & & \\
\hline & $3233 / 3$ & & & & & & & & & \\
\hline & $3221 / 2$ & & & & & & & & & \\
\hline & $3042 / 3$ & 39.69 & 15.20 & 10.26 & 34.89 & 354 & 0.68 & 2.61 & 0.29 & 0.34 \\
\hline \multirow[t]{2}{*}{3.} & $3142 / 2$ & & & & & & & & & \\
\hline & $3041 / 3$ & 37.87 & 18.17 & 8.67 & 35.30 & 377 & 0.48 & 2.08 & 0.25 & 0.41 \\
\hline \multirow[t]{2}{*}{4.} & $3281 / 3$ & & & & & & & & & \\
\hline & $\begin{array}{l}3051 / 1 \\
3031 / 3\end{array}$ & 37.03 & 20.67 & 11.20 & 31.07 & 336 & 0.54 & 1.79 & 0.36 & 0.49 \\
\hline
\end{tabular}

* The numerator denotes the number of all samples falling into the respective cluster; the denominator stands for the total number of samples.

could locally take part in forming contact subtypes. Eight samples from the Märjamaa, four from the Neeme, and one from the Naissaare pluton are included in cluster $\mathrm{C}_{4}$. The association $\mathrm{A}+\mathrm{B}+\mathrm{C}_{4}$ occurs at least in three plutons typical of Estonian granite plutons. The available data are insufficient to interpret the evolutionary relations of $\mathrm{C}_{4}$ and other granites unambiguously. Cluster $C_{5}$ includes eleven samples of the Neeme, Märjamaa, Naissaare, and Ereda plutons. By $c / f m$ ratio (0.5) these granites display some similarities to $E(0.53)$ and $F(0.47)$ granites, but their c/alk ratios show similarities to $\mathrm{B}$ and $\mathrm{D}$ granites. Thus, $\mathrm{C}_{5}$ granites reveal the petrochemical features of both end-members. In three drill cores of the Neeme pluton $(504,535$, and 537$)$ the association $\mathrm{C}_{5}+\mathrm{D}+\mathrm{B}$ has been observed (Fig. 4), displaying once more the diversity of granite evolution processes.

Proceeding from the results of cluster analysis, the average chemical composition corresponding to each cluster was calculated and presented in Table 2. In addition, the standard deviation, variation, and real chemical analyses were presented for the assessment of the homogeneity of data. Ordering the subtypes of granites by $\mathrm{SiO}_{2}$ content, positive and negative correlation between $\mathrm{Al}$ and $\mathrm{Si}$, and $\mathrm{Ti}, \mathrm{Fe}, \mathrm{Mn}, \mathrm{Mg}$, $\mathrm{Ca}$ and $\mathrm{Si}$, respectively, can be observed.

For estimating the petrochemical variation within the Märjamaa pluton, cluster analysis using 36 chemical analyses from 15 drill cores was used. These granites form four separate clusters (Table 3 ). This clustering subdivides the melanocratic part of granites into three subclusters, thus expressing the chemical inhomogeneity quite well also for more basic 

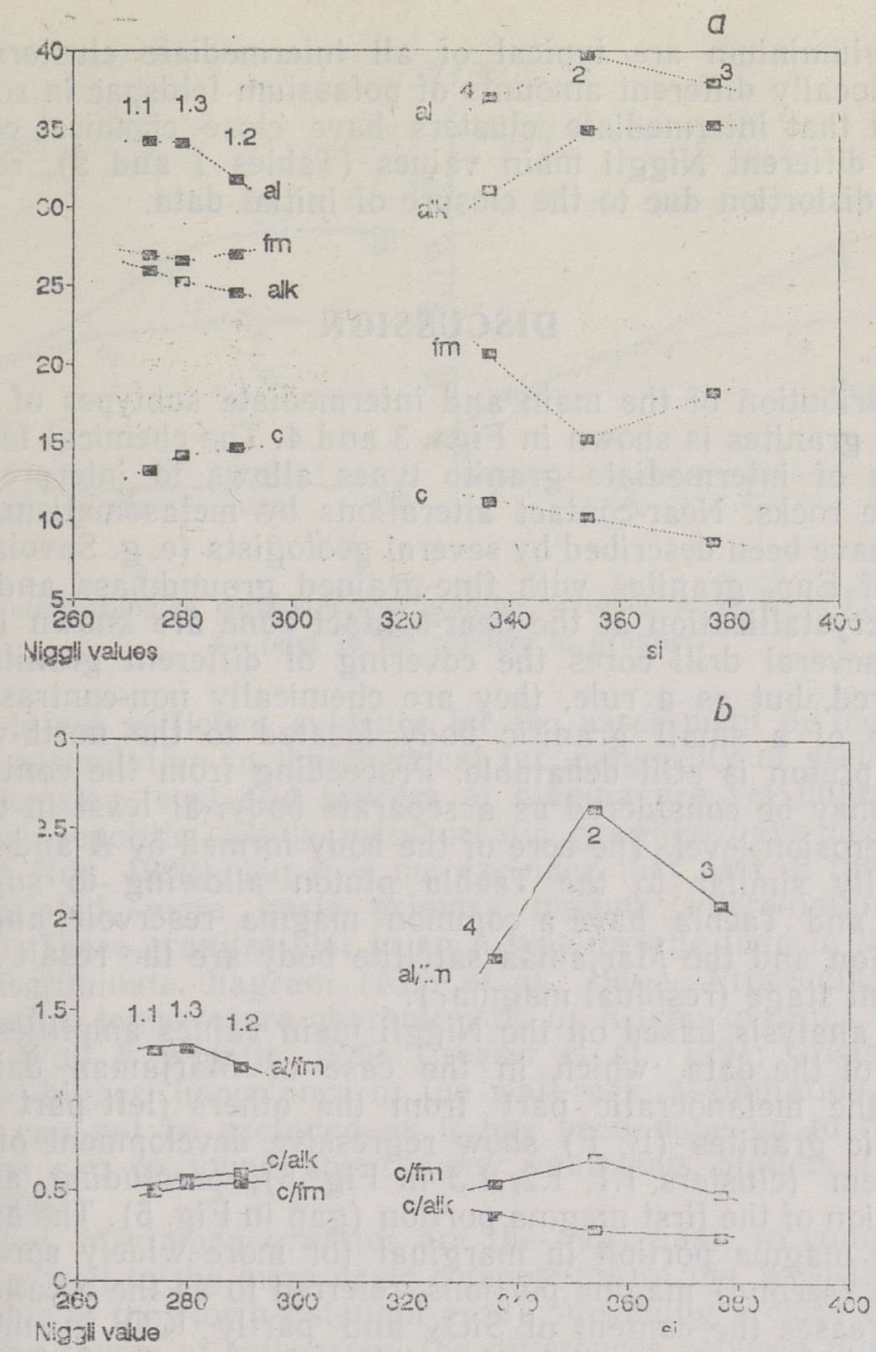

Fig. 5. Variation diagram of Märjamaa porphyraceous granites based on Niggli main values distinguished using cluster analysis. a-based on Niggli main values, and $b$-based on ratios.

granite types. The petrochemical differences of the rocks corresponding to the subclusters are likewise related to local processes causing the inclination from "normal" trend of magma evolution (see Fig. 5: fm and c increase, alk decreases).

Statistical assessment of data. Against the background of homogeneous chemical composition of main clusters (subtypes) the anomalous fluctuation of one or two components expressed mainly by standard deviation and variation can be observed (Table 2). The chemical inhomogeneity inside cluster $A$ caused by silicon and the fluctuation of potassium and sodium in cluster $\mathrm{B}$ are typical. $\mathrm{SiO}_{2}, \mathrm{FeO}$, and $\mathrm{K}_{2} \mathrm{O}$ contents vary in cluster $\mathrm{E}$ reflecting the silification and feldspathization of the melanocratic granites. D granites, as mentioned above, show well expressed chemical homogeneity. Stability of $\mathrm{Mg}$ and $\mathrm{Ca}$ is characteristic of all main clusters.

The homogeneity of the intermediate clusters is more pronounced comprising more than two elements, while the instability of silicon, potass- 
ium, and aluminium are typical of all intermediate clusters, possibly caused by locally different amounts of potassium feldspar in rock.

The fact that intermediate clusters have close chemical composition but rather different Niggli main values (Tables 1 and 2), reflects distinctly the distortion due to the closure of initial data.

\section{DISCUSSION}

The distribution of the main and intermediate subtypes of Märjamaa and Neeme granites is shown in Figs. 3 and 4. The chemical features and distribution of intermediate granite types allows to interpret them as contact-type rocks. Near-contact alterations by metasomatism, fluoridization, etc. have been described by several geologists (e. g. Savolahti, 1962) Varieties of Epp. granites with fine-grained groundmass and traces of periodical crystallization at the near-contact zone are known (Кууспалу, 1975). In several drill cores the covering of different granite varieties was observed, but as a rule, they are chemically non-contrastive types. The nature of a small granitic body located to the north-west of the Märjamaa pluton is still debatable. Proceeding from the contact-granite concept it may be considered as a separate body, at least in the context of present erosion level. The core of the body formed by $\mathrm{A}$ and $\mathrm{B}$ granites is chemically similar to the Taebla pluton allowing to suppose that Märjamaa and Taebla have a common magma reservoir and both the Taebla pluton and the Märjamaa satellite body are the result of the last emplacement stage (residual magma?).

Cluster analysis based on the Niggli main values amplifies the inner legitimacy of the data which in the case of Märjamaa data sharply separates the melanocratic part from the others (left part in Fig. 5). Melanocratic granites $(\mathrm{E}, \mathrm{F})$ show regressive development of the magmatic system (clusters 1.1, 1.2, 1.3 in Fig. 5), precluding any further differentiation of the first magma portion (gap in Fig. 5). The assimilation of the first magma portion in marginal (or more widely spread) zones by the next (second) magma portions, referred to as the second intrusion phase, increases the content of $\mathrm{SiO}_{2}$ and partly $\mathrm{K}_{2} \mathrm{O}$ in melanocratic varieties. As there are no data describing the spread of the mentioned "reaction," it may be speculated that it was the main reason why petrochemical and petrological inhomogeneities emerged in the central part of the pluton. More acid granite subtypes (second intrusive phase; clusters $2,3,4 ; \mathrm{A}+\mathrm{B}+\mathrm{C}_{4}+\mathrm{C}_{5}$ in Fig. 3) represent the product of several processes, such as assimilation (first phase), fractional crystallization, and/or gravitational differentiation, which depend partly on the geometry of contact zones with surrounding rocks and metasomatical alteration (muscovite-bearing granites).

The nature of the more leucocratic Neeme pluton may be explained by less frequent occurrences of the melanocratic phase (first magma portion) in the erosion level.

Fig. 6 presents the evolutionary trend of Epp. granites through $\mathrm{c} / \mathrm{fm}$ vs. $s i$ and $c / f m$ vs. al/fm, discriminating well the intermediate subtypes $\mathrm{C}_{1}, \mathrm{C}_{2}, \mathrm{C}_{4}$, and $\mathrm{C}_{5} . \mathrm{C}_{3}$ granites are linked to the main types $\mathrm{A}$ and $\mathrm{D}$. The assumption of dichotomy in magmatic evolution in the discrimination range of about $300<s i<350$ may facilitate the interpretation of intermediate and B granites. Generally, A and B granites represent the second intrusive stage, and dichotomy of evolution may have been induced by diversity of co-occurrent processes. The evolution of this period may be described as a reaction of the new magma portion with the earlier phase, which according to the petrographical evidence was not entirely cooled, 


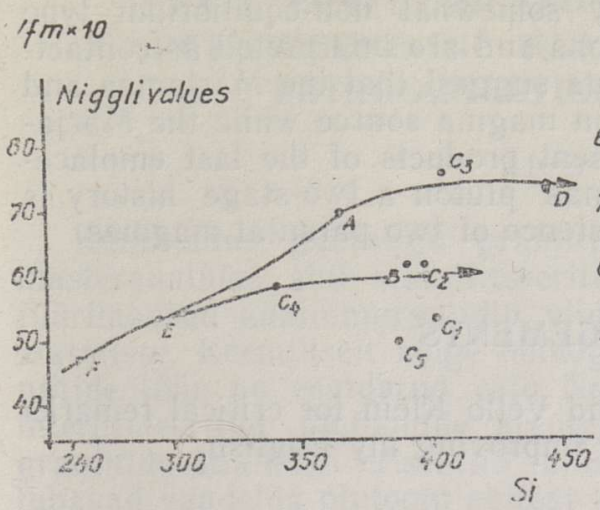

Fig. 6. Evolution trend of porphyraceous granites, Estonia. A, B, D, E, F, C $1, C_{2}, C_{3}, C_{4}$, $\mathrm{C}_{5}$ refer to the clusters of granites.

There is not sufficient evidence for the assessment of the role of the wall-rock assimilation in the chemical inhomogeneity of plutons, and the depth of erosion level and sources of magma are yet unknown. Partly assimilated xenoliths inside melanocratic granites have been described (Soesoo \& Niin, 1992), but it is not excluded that part of these represent undifferentiated, more basic primary magma intercalations (magma mingling). These granites plot in an A-type granite field in Whalen et al. (1987) discriminate diagram (Kirs et al., 1991). Proceeding from high crystallization temperature characteristic of A-type granites (Clemens et al., 1986; Wolf \& Whyllie, 1989; Creaser et al., 1991; Creaser \& White, 1991) the higher importance of the wall-rock assimilation in chemical evolution can not be excluded as it has been done up to now. Similar discussions can be found about many analogous plutons (Whalen and Currie, 1990).

As noted, Märjamaa granites are the most basic in composition corresponding well to the more basic composition of the West-Estonian area (comparable to the North-Estonian area). Assuming a close erosion depth and magma source of both areas, the differences between plutons may be expanded to the geological-structural differences of the North- and WestEstonian areas induced chemically by somewhat different primary magma (s).

\section{CONCLUSIONS}

Results of the petrochemical study of Estonian porphyraceous granites obtained with the help of cluster analysis indicate that these granites show chemical inhomogeneities on the erosion level of separate plutons and in some cases inside the drill core induced by many co-existent processes, such as assimilation (first intrusive phase) and secondary alteration. Also, the geometry (especially in marginal zones) and size of the magmatic body have an impact on the homogeneity of plutons. Melanocratic granites $\left(\mathrm{SiO}_{2}<=67 \%\right)$, chemically close to quartz-monzonite and granodiorite, occur mostly on the Märjamaa, in a limited amount on the Neeme pluton, and represent the rock of the first intrusive phase. More acid granites - subtypes $\mathrm{A}$ and $\mathrm{B}$ (average $\mathrm{SiO}_{2}=71.31-72.29$ ) - occur on the present erosion level of all the plutons (except the Ereda pluton) representing the second intrusion stage and reveal characteristics of more evolved magmatic systems with prints of secondary alteration. Granites whose composition is homogeneous (type D) form the central part of the Neeme pluton and can be referred to as the end-member of the granite 
evolution. Granites of petrochemically somewhat non-equilibrium type envelope the marginal zone of the plutons and are interpreted as contacttype granites. Several petrochemical data suggest that the Märjamaa and Taebla plutons may have had a common magma source while the Märjamaa satellite and Taebla pluton represent products of the last emplacement stage. At least for the Märjamaa pluton a two-stage history is evident, which does not exclude the existence of two parental magmas.

\section{ACKNOWLEDGEMENTS}

I thank my colleagues Juho Kirs and Vello Klein for critical remarks on the manuscript, and Ivar Puura for improving my English.

\section{REFERENCES}

Clemens, J., Holloway, J., White, A. 1986. Origin of an A-type granite: Experimental constraints. - American Mineralogist, 71, 317-324.

Creaser, R., Price, R., Wormald, R. 1991. A-type granites revisited: Assessment of a residual-source model. - Geology, 19, 163-166.

Creaser, R., White, A. 1991. Yardea Dacite-large-volume, high-temperature felsic volcanism from the Middle Proterozoic of South Australia. - Geology, 19, 48-51.

Kirs, J., Huhma, H., Haapala, I. 1991. Petrological-chemical features and age of Estonian postorogenic potassium granites. - In: Symposium on Rapakivi Granites and Related Rocks. Abstract, 28-29.

Russell, J., Stanley, R. 1990. A theoretical basis for the development and use of variation diagrams. - Geochimica et Cosmochimica Acta, 54, 2419-2431.

Savolahti, A. 1962. The Rapakivi problem and the rules of idiomorphism in minerals. Bull. Comm. Geol. Finland, 204.

Soesoo, A., Niin, M. 1992. Petrographical and petrochemical features of the Estonian Precambrian porphyraceous potassium granites. - Proc. Estonian Acad. Sci. Geol., 41, 3, 93-107.

Whalen, J., Currie, K., Chappell, B. 1987. A-type granites: Geochemical characteristics, discrimination and petrogenesis. - Contributions to Mineralogy and Petrology, 95, 407-419.

Whalen, J., Currie, K. 1990. The Topsailsigneous suite, western Newfoundland; Fractination and magma mixing in an "orogenic" A-type granite suite. - In: Stein, H. J. and Hannah, J. L. (eds.). Ore-bearing granite systems; Petrogenesis and mineralizing processes. Geological Society of America, Special Paper 246, $287-299$.

Wolf, M., Whyllie, P. 1989. The formation of tonalitic liquids during the vapor-absent partial melting of amphibolite at $10 \mathrm{~kb}$. [Abs.] Eos. (Transactions, American Geophysical Union), 70, 506.

Великославинский Д. А., Биркис А. П., Богатиков О. А., Бухарев В. П., Великославинский С. Д., Гордиенко Л. И., Зинченко О. В., Кивисилла Я. Я., Кирс Ю. Э., Кононов Ю. В., Левицкий Ю. Ф., Нийн М. И., Пуура В. А., Хворов М. И., Шустова Л. Е. 1978. Анортозит-рапакивигранитная формация, Восточно-Европейская платформа. Наука, Ленинград.

Қирс Ю., Пуура В., Биркис А., Кивисилла Я., Клейн В., Мотуза Г., Нийн М., Сууроя К. 1990. Новые данные о магматических комплексах фундамента Прибалтики. - In: Геология и геохронология докембрия Восточно-Европейской платформы. Наука, Ленинград, 155-166.

Кууспалу Т. 1975. Граниты рапакиви кристаллического фундамента Эстонии. - Уч. зап. ТГУ, вып. 359. Тр. по геологии, 76-142.

Пуура В., Мурина Г., Миркина С. 1974. Возраст порфировидных гранитов рапакиви Северной Эстонии по данным стронциевого и свинцового методов. - Изв. АН ӘССР, Хим, Геол., 23, 2, 169-171. 


\section{EESTI PORFÜURILAADSETE KAALIUMGRANIITIDE PETROKEEMILINE KLASSIFIKATSIOON JA SELLE PETROGENEETILINE TÕLGENDAMINE}

\section{Alvar SOESOO}

Kuuekümne puuraugu graniitide keemilisi analüüse kasutades on klasteranalüüsi abil klassifitseeritud Eesti eelkambriumi vanusega porfüürilaadsed kaaliumgraniidid viide petrokeemilisse põhi- ja viide lisaklastrisse. Keemiliselt kõige homogeensema koostisega leukokraatne graniitide tüüp on esindatud vaid Neeme plutooni tsentraalses osas ja on interpreteeritud plutoonide arengu lõppproduktina. Märjamaa plutooni graniitide analüüsil eristuvad aluselisem ja happelisem graniitide osa lubavad vaadelda plutooni ehitust kahe magmalise arengustaadiumi taustal. Olulised plutoonide keemilist ja kivimilist heterogeensust põhjustavad faktorid on: aluselisema esimese graniitse faasi assimilatsioon järgneva(te) faasi(de) mõjul, lokaalsed sekundaarsed muutused ning magma jahtumisiseärasused plutoonide ja külgkivimite kontaktialas.

\section{ПЕТРОХИМИЧЕСКАЯ КЛАССИФИКАЦИЯ И ВОПРОСЫ ПЕТРОГЕНЕЗИСА ПОРФИРОВИДНЫХ КАЛИЕВЫХ ГРАНИТОВ ЭСТОНИи}

\section{Алвар COECOO}

С использованием кластерного анализа и на основе чисел Ниггли (98 химических анализов) порфировидные калиевые граниты из 60 скважин Әстонии петрохимически подразделены на пять основных и пять дополнительных групп. Две из них с содержанием $\mathrm{SiO}_{2} 67 \%$ химически соответствуют кварц-монцонитам и гранодиоритам. Местоположение и петрохимический характер гранитов, входящих в состав дополнительных групп, позволяют интерпретировать их как породы приконтактового типа. Рассмотрено распространение подтипов гранитов в пределах Неэмеского и Мярьямааского плутонов. Химически малоизменчивый, наиболее кислый тип гранитов, встречающийся только в Неэмеском плутоне, представляет собой, вероятно, конечный продукт эволюции плутонов. Кластерный анализ разделяет мярьямааские граниты на два четко отличающихся друг от друга типа, что свидетельствует в пользу двухстадийного развития плутона. Основными факторами химической гетерогенности гранитных плутонов являются ассимиляция гранитов ранней стадии внедрения последующими порциями магм, а также характер застывания в приконтактовых зонах. 